\title{
ANALISIS WACANA KOHESI DAN KOHERENSI PADA TEKS CERPEN, TEKS PROSEDUR, TEKS LINGKUNGAN DAN KEMUNGKINAN PEMBELAJARAN DI SEKOLAH
}

Diajukan untuk memenuhi tugas akhir semester Wacana Bahasa Indonesia yang diampu oleh Prof. Dr. Syahrul Ramadhan, M.Pd.

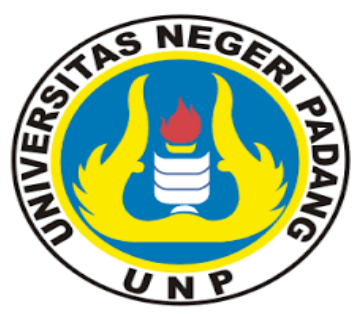

OLEH

BIMA SATI / 17016007

No. Urut : 1

PROGRAM STUDI PENDIDIKAN BAHASA DAN SASTRA INDONESIA DAN

DAERAH

JURUSAN BAHASA DAN SASTRA INDONESIA

FAKULTAS BAHASA DAN SENI

UNIVERSITAS NEGERI PADANG

2020 


\section{KATA PENGANTAR}

Puji dan syukur atas kehadirat Allah SWT yang telah memberikan rahmat dan karuniaNya sehingga, makalah ini dapat penulis selesaikan dengan judul materi "Analisis Wacana Kohesi dan Koherensi pada Teks Cerpen, Teks Prosedur, Teks Lingkungan dan Kemungkinan Pembelajaran di Sekolah". Salawat dan salam kepada Nabi Muhammad SAW, yang telah telah membawa umat manusia dari zaman kebodohan menuju zaman yang terang benderang seperti saat ini.

Penulis mengucapkan terima kasih kepada Prof. Dr. Syahrul Ramadhan, M.Pd. selaku dosen mata kuliah wacana bahasa Indonesia yang telah memberikan ilmunya kepada penulis dan sumbangan moril dalam menyelesaikan makalah ini. Penulis menyadari bahwa dalam penyusunan makalah ini masih jauh dari kesempurnaan, karena adanya keterbatasan ilmu pengetahuan yang penulis miliki. Namun, demikian penulis berharap semoga makalah ini dapat bermanfaat bagi pembaca pada umumnya dan penulis khususnya. Penulis sangat berharap kritik dan saran dari para pembaca agar lebih baik lagi kedepannya.

Padang, 2 Juni 2020

Penulis 


\section{BAB I \\ PENDAHULUAN}

\section{A. Latar Belakang}

Menurut Poerwadarminta (dalam Baryadi, 2002:1) kata wacana berasal dari kata vacana 'bacaan' dalam bahasa Sanskerta. Kata vacana itu termasuk ke dalam bahasa Jawa Kuno dan bahasa Jawa Baru wacana atau 'bicara, kata, ucapan'. Kata wacana dalam bahasa Jawa Baru itu kemudia diserap ke dalam bahasa Indonesia menjadi wacana 'ucapan, percakapan, kuliah'. Berbeda halnya dengan pendapat Sumarlam (dalam Widiatmoko, 2015) wacana yang baik adalah wacana yang harus memperhatikan hubungan antarkalimat, sehingga dapat menjaga keterkaitan dan keruntutan antarkalimat. Sejalan dengan pandangan bahwa bahasa itu terdiri atas bentuk dan makna, hubungan dalam wacana dapat dibedakan menjadi dua jenis yaitu hubungan bentuk yang disebut kohesi dan hubungan makna atau hubungan semantis yang disebut koherensi.

Menurut Alwi, et al (dalam Nurfitriani, et al, 2018) wacana adalah sebuah rentetan kalimat yang menghubungkan prosisi lain dan membentuk satu kesatuan. Di samping itu, wacana merupakan kesatuan bahasa terlengkap dan terbesar dari kalimat atau klausa dengan kohesi dan koherensi yang tinggi dan berkesinambungan, yang mampu mempunyai awal dan akhir yang nyata, serta dapat disampaikan secara lisan dan tertulis. Sedangkan menurut Hanafiah (2014) wacana adalah komunikasi verbal, percakapan, keseluruhan tutur yang merupakan suatu kesatuan.

Menurut Siregar (2019) wacana adalah unit bahasa yang terlengkap di atas kalimat yang memiliki konsep, gagasan, pikiran, atau ide yang dapat dipahami oleh pembaca dan pendengar. Sedangkan menurut Kridalaksana (dalam Insani, 2018) wacana merupakan satuan bahasa terlengkap dan satuan gramatikal tertinggi dalam hierarki gramatikal. Sebagai tataran tertinggi dalam hierarki kebahasaan, wacana tidak merupakan susunan kalimat secara acak, tetapi merupakan satuan bahasa, baik lisan maupun tulis. Berbeda dengan pendapat Widyaningrum (2017) wacana merupakan tingkatan yang paling tinggi di dalam hierarki pembicaraan sintaksis setelah frase, klausa dan kalimat. Wacana juga suatu tulisan yang dapat berupa kata, kalimat, paragraf, bab atau beberapa bab. Berdasarkan pendapat para ahli tersebut, dapat disimpulkan 
wacana merupakan satuan bahasa terlengkap dan satuan gramatikal tertinggi dalam hierarki gramatikal dengan kohesi dan koherensi yang tinggi dan berkesinambungan.

\section{B. Rumusan Masalah}

1. Bagaimana analisis wacana kohesi dan koherensi dalam teks cerpen ?

2. Bagaimana analisis wacana kohesi dan koherensi dalam teks prosedur ?

3. Bagaimana analisis wacana kohesi dan koherensi dalam teks lingkungan?

4. Bagaimana kemungkinan pembelajaran ketiga wacana tersebut di sekolah ?

\section{Tujuan Penulisan}

1. Untuk mendeskripsikan analisis wacana kohesi dan koherensi dalam teks cerpen.

2. Untuk mendeskripsikan analisis wacana kohesi dan koherensi dalam teks prosedur.

3. Untuk mendeskripsikan analisis wacana kohesi dan koherensi dalam teks lingkungan.

4. Untuk mendeskripsikan kemungkinan pembelajaran ketiga wacana tersebut di sekolah. 


\section{BAB II \\ KAJIAN PUSTAKA}

Menurut Baryadi (2002:17-29) untuk menciptakan keutuhan, bagian-bagian wacana harus saling berhubungan. Hubungan antarbagian wacana dapat dibedakan menjadi dua jenis, yaitu hubungan benuk yang disebut kohesi dan hubungan makna atau hubungan semantis yang disebut koherensi. Kohesi berkenaan dengan hubungan bentuk antara bagian-bagian dalam suatu wacana. Kohesi dapat dibedakan menjadi dua jenis yaitu kohesi gramatikal, kohesi yang keterkaitan gramatikal antara bagian-bagian wacana, dan kohesi leksikal, kohesi yang keterkaitan leksikal antara bagian-bagian wacana. Kohesi gramatikal dapat dirinci lebih lanjut menjadi penunjukan, penggantian, pelesapan, dan perangkaian. Sedangkan kohesi leksikal dapat dirinci lebih lanjut menjadi pengulangan, hiponimi, sinonimi, antonimi, dan kolokasi. Koherensi adalah keterkaitan semantis antara bagian-bagian wacana. Ada berbagai jenis koherensi antara lain, wacana eksposisi, wacana deskripsi, wacana narasi, wacana prosedural, dan wacana dialog.

Pembelajaran di sekolah sangat penting bagi siswa dalam menulis berbagai teks. Seperti teks cerpen, teks prosedur, teks lingkungan, dan teks lainnya. Sementaraa itu, Putri, et al (2013) dalam pembelajaran lesson study merupakan model profesi guru dengan menerapkan tiga prinsip pembelajaran yang harus dilakukan oleh guru yaitu, perencanaan, pelaksanaan, dan refleksi. Pembelajaran lesson study diharapkan dapat meningkatkan kreativitas dan hasil belajar siswa. Pembelajaran di kelas perlu adanya percakapan yang efektif antara guru dengan siswa. Ramadhan (2008) menyatakan percakapan dalam pembelajaran di kelas merupakan realitas komunikasi menggunakan bahasa yang berlangsung dalam interaksi sosial, karena pada prinsipnya, percakapan tersebut menggunakan bahasa sebagai alat komunikasi dalam interaksi sosial. Menurut Ramadhan, et al (2019) guru harus mengadaptasi metode pengajaran mereka sehingga mereka dapat memotivasi siswa untuk terlibat dalam pembelajaran partisipatif aktif.

Alat komunikasi dalam bahasa bukan hanya interaksi soasial saja, tetapi dengan literasi siswa juga dapat berbahasa. Sukma, et al (2018) menyatakan literasi dapat dipahami sebagai keterampilan memaham huruf, dan juga kemampuan membaca dan menulis. Sukma, et al (2019) berpendapat bahwa literasi sangat penting bagi siswa karena keterampilan literasi akan berpengaruh terhadap keberhasilan belajar mereka dan kehidupannya. Keterampilan membaca yang baik akan membantu siswa memahami teks lisan, tulisan, maupun teks visual. Menurut 
Sukma, et al (2017) sebagai dasar keterampilan membaca harus intens dan tegas, oleh karena itu kegiatan membaca pendahuluan harus dilayani dan diimplementasikan dengan sunggu-sungguh.

Hafizah, et al (2018) berpendapat bahwa siswa dinyatakan mampu menulis teks cerpen apabila teks yang ditulis siswa sesuai dengan indikator berikut, (1) siswa mampu menulis kelengkapan struktur teks cerpen, (2) siswa mampu menulis unsur pembangun teks cerpen, (3) siswa mampu menulis struktur kebahasaan teks cerpen, dan (4) siswa mampu menulis teks cerpen sesuai diksi yang baik. Teks prosedur juga penting dipelajari siswa. Pradana (dalam Arviyana, et al, 2017) mengatakan bahwa pembelajaran menulis teks prosedur menjadi penting karena setiap siswa mampu memahami dan mengutarakan idenya.

Bukan hanya teks cerpen dan teks prosedur saja yang penting dalam pembelajaran di sekolah, tetapi teks lingkungan juga sangat penting agar siswa dapat mengetahui serta menjaga lingkungan dengan baik dan bersih. Menurut Ramadhan, et al (2019) pendidikan lingkungan adalah upaya bersama yang secara sudah diatur untuk mengajarkan atau menarik perhatian manusia tentang bagaimana fungsi lingkungan alam dan bagaimana manusia dapat mengelola dan melindunginya. Sedangkan Guci, et al (2016) berpendapat bahwa korelasi antar berbagai oganisme hidup atau makhluk hidup di dalam lingkungannya merupakan sesuatu yang alami terjadi. Hubungan ini sangat penting dijaga keserasian dan keseimbangannya agar berjalan sesuai dengan seharusnya.

\section{BAB III PEMBAHASAN}

Menurut Baryadi (2002:17-38) kohesi dapat dibedakan menjadi dua jenis yaitu kohesi gramatikal, kohesi yang keterkaitan gramatikal antara bagian-bagian wacana, dan kohesi leksikal, kohesi yang keterkaitan leksikal antara bagian-bagian wacana. Kohesi gramatikal dapat dirinci lebih lanjut menjadi, (1) penunjukan, penunjukan adalah salah sau jenis kohesi gramatikal yang berupa satuan lingual tertentu yang menunjuk satuan lingual yang mendahului atau mengikutinya. Berdasarkan arah penunjukannya, kohesi penunjukan dapat dibedakan menajdi dua jenis, penunjukan anaforis dan penunjukan kataforis. (2) penggantian, penggantian adalah kohesi gramatikal yang berupa penggantian konstituen tertentu dengan konstituen lain. (3) 
pelesapan, pelesapan adalah kohesi gramatikal yang berupa pelesapan (zero) konstituen yang telah disebut. Dan (4) perangkaian, perangkaian adalah kohesi gramatikal yang berwujudk konjungsi.

Kohesi leksikal dapat dirinci lebih lanjut menjadi (1) pengulangan, pengulangaan adalah kohesi leksikal yang berupa pengulangan konstituen yang telah disebut. (2) hiponimi,hiponimi adalah kohesi leksikal yang berupa relasi makna leksikal yang bersifat hierarkis antara kostituen yang satu dengan konstituen yang lain. (3) sinonimi, sinonimi adalah kohesi leksikal yang berupa relasi makna leksikal yang mirip antara konstituen yang satu dengan konstituen yang lain. (4) antonimi, antonimi adalah kohesi leksikal yang berupa relasi makna leksikal yang bersifat kontras atau berlawanan antara konstituen yang satu dengan konstituen yang lain, dan (5) kolokasi, kolokasi adalah kohesi leksikal yang berupa relasi makna yang berdekatan antara konstituen yang satu dengan konstituen yang lain.

Koherensi adalah keterkaitan semantis antara bagian-bagian wacana. Ada lima jenis koherensi antara lain, (1) wacana eksposisi, didominasi oleh koherensi logis, misalnya kausalitas, kontras, aditif, rincian, dan temporal. (2) wacana deskripsi, didominasi oleh koherensi perian. (3) wacana narasi, didominasi oleh koherensi kronologis atau hubungan rangkaian waktu. (4) wacana prosedural, didominasi oleh koherensi pentahapan yaitu tahap-tahap terjadinya peristiwa, dan (5) wacana dialog, didominasi oleh koherensi stimulus-respon, misalnya fatis, informatif, pengukuhan, penolakan, dan negosiatif.

Berikut ini adalah analisis wacana kohesi dan koherensi dalam teks cerpen, teks prosedur, teks lingkungan, dan kemungkinan pembelajaran ketiga wacana tersebut di sekolah.

\section{A. Analisis Wacana Kohesi dan Koherensi dalam Teks Cerpen}

\section{Analisis Wacana Kohesi}

Berikut analisis wacana kohesi gramatikal dalam teks cerpen " Parmin " karya Jujur Prananto yaitu:

Berdasarkan cerpen Parmin karya Jujur Prananto diatas maka dapat saya simpulkan

1. Kohesi 
Dalam cerpen Parmin ini terdapat kohesi gramatikal yaitu penunjukan, penggantian dan perangkaian. Kohesi ini dapat ditemukan langsung pada bagian pengenalan cerpen yaitub pada kalimat : "Mencurigai. Betapa tidak enaknya perbuatan ini. Bahkan terhadap orang yang patut dicurigai sekalipun. Lebih tidak enak lagi kalau orang itu adalah Parmin. Tukang kebun yang rajin dan tak banyak cakap itu. Yang kerjanya cekatan, dengan wajah yang senantiasa memancarkan kesabaran. Kadang ia membangkitkan rasa iba, tanpa ia bersikap meminta. Parmin justru banyak memberi, Cuma jarang begitu disadari. Tapi keadaan telah berubah. Semenjak pesta ulang tahun papi beberapa hari yang lalu, senyum itu tak lagi akrab dengan wajah lugunya. Tak ada yang bisa memaksa Parmin untuk mengatakan sesuatu sehubungan dengan kemurungannya itu selain ucapan."Saya tidak apa-apa"

Nah pada analisis kalimat diatas terdapat kohesi penunjukan seperti pada kalimat yang digarisbawahi terdapat penunjuk kata ini dan itu untuk menggambarkan situasi.

Pada kalimat selanjutnya " Kadang ia " Ia merupakan kohesi pengganti. Pada kohesi perangkaian juga dapat ditemukan pada kalimat “ Tukang kebun yang rajin dan tak banyak cakap itu. Yang kerjanya cekatan, dengan wajah yang senantiasa memancarkan kesabaran”. Dalam pernyataan ini terdapat kalimat perangkaian dari kata “ Yang, dan Dengan ". Contoh seperti ini juga dapat ditemukan sampai paragraf akhir cerpen ini.

\section{Analisis Wacana Koherensi}

Dalam cerpen Parmin ini jika ditinjau dari segi koherensinya juga telah memenuhi syarat koherensi yairtu keterpaduan. Dalam cerpen ini dapat ditemukan dari segi tata bahasa yang digunakan pengarang telah mengarah pada koherensi logis misalnya kausalitas, rincian, auditif dan temporal.

Bukti kalimatnya dapat kita temukan mulai dari paragraf pembuka, paragraf isi, dan paragraf penutupnya. Rinciannya sebagia berikut ini :

Mencurigai. Betapa tidak enaknya perbuatan ini. Bahkan terhadap orang yang patut dicurigai sekalipun. Lebih tidak enak lagi kalau orang itu adalah Parmin. Tukang kebun yang rajin dan tak banyak cakap itu. Yang kerjanya cekatan, dengan wajah 
yang senantiasa memancarkan kesabaran. Kadang ia membangkitkan rasa iba, tanpa ia bersikap meminta. Parmin justru banyak memberi, Cuma jarang begitu disadari. Tapi keadaan telah berubah. Semenjak pesta ulang tahun papi beberapa hari yang lalu, senyum itu tak lagi akrab dengan wajah lugunya. Tak ada yang bisa memaksa parmin untuk mengatakan sesuatu sehubungan dengan kemurungannya itu selain ucapan."Saya tidak apa-apa"

Rasanya berat untuk berpikiran bahwa orang seperti dia bisa melakukan tindak tak terpuji. Tapi apa boleh buat, ada dugaan kuat bahwa paling tidak dia telah berbuat salah yang membuatnya begitu resah. Dan inilah peristiwa yang mengawali kecurigaan itu, seperti berulang kali di ceritakan mami.

Parmin mencuri? Itu lah kemungkinan yang paling dikhawatirkan. Harihari sebelumnya sebenarnya belum ada petunjuk ke arah itu. Bahkan hari sabtu, pada siangnya pesta itu akan berlangsung, pagi-pagi ia datang masih dengan penampilan cerah seperti biasa. Kapan dan mengapa? Sekitar pukul sepuluh ia membantu parjilah berbelanja kebeberapa rumah makan, pasar, dan supermarket. Selanjutnya pekerjaan permin tidak berat: menyimpan es krim, menghidangkannya bila ada tamu yang berminat. Segalanya berjalan beres.

Adalah sangat mengagetkan ketika keesokan harinya ia tetap muncul, walau masih dengan kegelisahan dan kegugupannya. Nampak lesu, bekerja tanpa gairah, parmin kemudian meminta izin pulang awal dengan alasan kurang enak badan. Tapi, keesokan harinya lagi, yakni dua hari setelah pesta ulang tahun papi, Parmin tidak masuk! Bisa jadi 'sang tikus'berhasil berbelit dari perangkap. Tapi berati pula ada kesempatan menyelidiki. Dapur diteliti, gudang belakang di bongkar.

Diamati seksama apakah terdapat kerusakan pada pintu-pintu, dan yang penting adalah barang-barang di dalam yang hilang, yang kira-kira paling berharga dan bisa menarik perhatian orang yang "sudah lama melakukan pengamatan dengan menyamar sebagai tukang kebun". Walhasil, kerja seharian sana-sini tak menghasilkan apa-apa selain rangkaiaan nostalgia dan seonggok dabu. Jadi bisa saja parmin tidak mengambil apa-apa, pada saat itu. Tapi belum tentu untuk harari-hari mendatang, sebagaimana ditandaskan oleh tante tatik, kakak papi tertua, ketika dihubungi mami lewat telepon

Nah, berdasarkan kutipan cerpen yang digarisbawahi dengan dicetak tebal maka terdapat hubungan koherensi kausal, aditif, dan rincian, yang kesemuanya itu membentuk sebuah keterpaduan dalam cerpen ini. Kohesi dan koherensi dalam cerpen " Parmin " karya Jujur Prananto ini sangat baik sehingga pembaca merasa sangat nyaman daan tertarik dalam membaca cerpen karena memiliki keterkaitan antarkalimat yang baik, dan keterpaduan antarkalimat yang baik pula sehingga menjadi kalimat cerita yang mengagumkan. 


\section{B. Analisis Wacana Kohesi dan Koherensi dalam Teks Prosedur}

\section{Analisis Wacana Kohesi}

Berikut analisis wacana kohesi gramatikal dalam teks prosedur "Membuat Nasi Goreng Yang Enak” yaitu

Dalam teks diatas terdapat kesinambungan kalimat. Hal ini dapat kita lihat dalam hal ini pada pembukaan dalam teks prosedur cara membuat nasi goreng yang enak ini. Kemudian dilanjutkan dengan menjelaskan bahan dan alat yang akan digunakan untuk membuat nasi goreng itu. Ini dapat kita lihat dalam kutipan teks sebagai berikut ini :

Nasi goreng adalah salah satu menu masakan Indonesia yang telah mendunia. Selain enak, masakan ini juga sangat mudah dibuat. Selain itu, nasi goreng juga mengandung gizi yang seimbang dan komplit, mulai dari karbohidrat dari nasi itu sendiri, vitamin A, dan B karena terdapat berbagai macam bawang dan sayur rempah, serta protein yang tinggi karena juga dilengkapi dengan telur ayam. Berikut ini adalah teks prosedur membuat nasi goreng.

Bahan-bahan:

1. 1 piring nasi putih

2. 1 butir telur

3. Gula dan garam

4. Penyedap rasa

5. 1 siung bawah merah

6. 1 siung bawang putih

7. Mentega atau minyak goreng

8. Kecap dan saus

9. Cabai (Bagi yang suka makanan pedas)

Alat-alat:

1. Kompor

2. Wajan

3. Spatula

4. Piring

Cara Membuat: 
1. Haluskan bahan-bahan seperti bawang merah, bawang putih dan cabai (sesuai selera).

2. Kocok telur di dalam mangkuk (jika ingin membuat nasi goreng orak-arik).

3. Panaskan minyak goreng. Karena dengan suhu yang panas maka akan mendapatkan hasil yang baik.

4. Goreng telur terlebih dahulu dan sisihkan di sisi wajan.

5. Masukkan bahan yang sudah dihaluskan dan tunggu hingga setengah matang.

6. Masukkan nasi dan bahan lain seperti penyedap rasa, kecap dan saus jika ingin.

7. Campurkan telur yang sudah disisihkan.

8. Aduk hingga semua bumbu tercampur merata.

9. Letakkan di atas piring

10. Nasi goreng siap disajikan.

\section{Analisis Wacana Koherensi}

Dari kutipan wacana di atas, kesinambungan topiknya cukup tinggi hal ini dapat dilihat dari keterkaitan antar topik serta tulisan antar konstituen yang saling berkaitan dengan susunan dalam pola SV. Mulai dari kalimat tesis atau pembuka dalam teks tersebut yang mengacu kepada penjelasan mengenai cara membuat nasi goreng yang enak, lalu terdapat penjelasan mengenai bahan-bahan yang akan digunakan, hingga langkah-langkah dalam membuat nasi goreng itu sendiri. Sehingga kesinambungan yang ideal dan baik terdapat dalam teks tersebut. Dalam kalimat tersebut "Nasi goreng adalah salah satu menu masakan Indonesia yang telah mendunia. Selain enak, masakan ini juga sangat mudah dibuat. Selain itu, nasi goreng juga mengandung gizi yang seimbang dan komplit, mulai dari karbohidrat dari nasi itu sendiri, vitamin A, dan B karena terdapat berbagai macam bawang dan sayur rempah, serta protein yang tinggi karena juga dilengkapi dengan telur ayam. Berikut ini adalah teks prosedur membuat nasi goreng".

\section{Analisis Wacana Kohesi dan Koherensi dalam Teks Lingkungan}

\section{Analisis Wacana Kohesi}


Kerusakan lingkungan hidup dapat diartikan sebagai proses deteriorasi atau penurunan mutu (kemunduran) lingkungan. Deteriorasi lingkungan ini ditandai dengan hilangnya sumber daya tanah, air, udara, punahnya flora dan fauna liar, dan kerusakan ekosistem.

Kerusakan lingkungan hidup di Indonesia semakin hari kian parah. Kondisi tersebut secara langsung telah mengancam kehidupan manusia. Tingkat kerusakan alam pun meningkatkan resiko bencana alam. Penyebab terjadinya kerusakan alam dapat disebabkan oleh dua faktor yaitu akibat peristiwa alam dan akibat ulah manusia.

Kerusakan yang disebabkan oleh manusia ini justru lebih besar dibanding kerusakan akibat bencana alam. Ini mengingat kerusakan yang dilakukan bisa terjadi secara terus menerus dan cenderung meningkat.

Letusan gunung berapi, banjir, abrasi, tanah longsor, angina puting beliung, gempa bumi, dan tsunami merupakan beberapa contoh bencana alam. Bencana-bencana tersebut menjadi penyebab rusaknya lingkungan hidup akibat peristiwa alam.

Kerusakan ini umumnya disebabkan oleh aktifitas manusia yang tidak ramah lingkungan seperti perusakan hutan dan ahli fungsi hutan, pertambangan, pencemaran udara, air, dan tanah dan lain sebagainya.

Pada analisis kohesi teks bertemakan lingkungan tersebut terdapat hubungan kohesi penunjukan, pelesapan, penghilangan, dan pengulangan. Seluruh kohesi ini dapat terlihat bahwa kata ini berfungsi sebagai penanda kohesi penunjukan anaforis baik berdiri sendiri, didahului nomina umum, atau didahului konjungsi. Penggantian terdapat pada kata nya, kalimat tersebut terlihat bahwa kata nya yang dipakai untuk kohesi penggantian persona yang bersifat diektis. Oleh sebab itu, kata-kata tersebut disebut "dieksis persona. Sedangkan kohesi pelesaapan dan penghilangan terlihat pada konstituen $\varnothing$, kohesi tersebut terlihat bahwa konstituen $\varnothing$ pada kalimat tersebut memiliki referensi yang sama dengan letusan gunung berapi, banjir, abrasi, tanah longsor, angina putting beliung, gempa bumi, dan tsunami yang telah disebut. Pelesapan pengulangan terdapat dalam kalimat, terlihat bahwa kata akibat, pada kalimat topik diulang pada kalimat pengembang, sehingga kalimat-kalimat tersebut kohesif. 


\section{Analisis Wacana Koherensi}

Jika ditinjau dari segi koherensi maka teks yang berjudul "Kerusakan Lingkungan Hidup di Indonesia dan Penyebabnya" sangat koheren sekali sehingga ditinjau dari segi bahasa sangat terpadu sekali, karena sangat saling memiliki kaitan antara kata yang satu dengan kata yang lainnya, kalimat satu dengan yang lainnya, dan antar paragraf dengan paragraf yang lainnya. Hal ini dapat dilihat misalnya dilihat dalam perbandingan pada paragraf pertama dan kedua maka ditinjau dari seluruh keterpaduannya akan kita temukan sangat terpadu ( koheren ) :

Kerusakan lingkungan hidup dapat diartikan sebagai proses deteriorasi atau penurunan mutu (kemunduran) lingkungan. Deteriorasi lingkungan ini ditandai dengan hilangnya sumber daya tanah, air, udara, punahnya flora dan fauna liar, dan kerusakan ekosistem.

Kerusakan lingkungan hidup di Indonesia semakin hari kian parah. Kondisi tersebut secara langsung telah mengancam kehidupan manusia. Tingkat kerusakan alam pun meningkatkan resiko bencana alam. Penyebab terjadinya kerusakan alam dapat disebabkan oleh dua faktor yaitu akibat peristiwa alam dan akibat ulah manusia.

Pada paragraf satu dan dua diatas maka ditemukan tentang penjelasan mengenai kerusakan lingkungan dan penyebabnya, dapat dilihat pada kalimat dalam paragraf satu dan dua memiliki hubungan kausalitas yaitu sebab akibat yang tentunya memiliki koherensi antar kalimat dalam paragraf satu dan dua tersebut, sangat tinggi dan saling koheren.

\section{Kemungkinan Pembelajaran Ketiga Wacana tersebut di Sekolah}

Pembelajaran yang efektif di sekolah sangat perlu diterapkan baik dalam pembelajaran sekolah dasar sampai kepada tingkat sekolah menengah pertama. Pembelajaran di sekolah menggunakan berbagai jenis teks, termasuk ketiga jenis teks di atas yaitu teks cerpen, teks prosedur, dan teks lingkungan. Menurut Agustina (2017) teks dalam pembelajaran bahasa sesungguhnya bukan sesuatu yang baru. Hal itu sudah menjadi bagian dari komponen pembelajaran bahasa secara integrasi. Teks merupakan jalan menuju pemahaman tentang bahasa. 
Itu sebabnya teks, merupakan bahasa yang berfungsi atau bahasa yang melaksanakan tugas tertentu dalam konteks situasi. Menurut Mahsun (dalam Agustina, 2017) teks dapat didefinisikan sebagai satuan bahasa yang digunakan untuk ungkapan suatu kegiatan sosial baik secara lisan maupun tulis dengan struktur berpikir yang lengkap. Adanya teks cerpen siswa dapat menuangkan ide-idenya dengan membuat sebuah cerita yang mereka sukai. Teks prosedur siswa juga dapat menuangkan ide-idenya dan dapat mengetahui berbagai prosedur. Siswa dapat mengetahui bagaimana menjaga lingkungan di sekitar dengan baik melalui pembelajaran bahasa. Guru dapat mempelajari siswa bagaimana berkontribusi pada dunia yang lebih sehat dan berkelanjutan melalui teks lingkungan tersebut.

Menurut Isodarus (2017) ada lima kegiatan yang dapat dilakukan oleh siswa dalam belajar berbahasa Indonesia berbasis teks. Pertama, siswa mengidentifikasi informasi atau isi teks. Kedua, siswa menelaah struktur teks. Ketiga, siswa menentukan unsur-unsur kebahasaan suatu teks. Keempat, siswa membedakan teks yang satu dengan teks yang lain. Kelima, siswa memperbaiki penggunaan bahasa dalam teks. Keenam, siswa membuat teks. Berbagai kegiatan tersebut dilakukan oleh siswa dengan bimbingan atau pendampingan guru. Siswa juga dapat memperbaiki penggunaan bahasa Indonesia dalam jenis teks yang sedang dipelajari agar dimaksudkan agar siswa memahami kaidah atau tata bahasa Indonesia. Setelah memiliki pengetahuan tentang jenis teks yang akan dibuat, siswa mulai berlatih membuat teks dengan mendapat bimbingan yang intensif dari guru.

Menurut Isodarus (2017) agar dapat membimbing siswa melakukan kegiatan pembelajaran berbasis teks, guru perlu memiliki bekal pengetahuan yang memadai tentang teks. Sekurang-kurangnya guru memiliki pengetahuan tentang (1) jenis-jenis teks yang harus dipelajari oleh peserta didik dalam satuan pendidikan tertentu, (2) ciri isi setiap jenis teks, (3) ciri struktur setiap jenis teks, (4) ciri unsur-unsur bahasa setiap jenis teks, dan (5) ciri-ciri keseluruhan setiap jenis teks. Ketiga teks wacana tersebut digunakan di sekolah karena mudah dipahami oleh siswa, dan siswa juga dapat membuat teks tersebut dengan baik dan benar. 


\title{
BAB IV \\ PENUTUP
}

\section{A. Kesimpulan}

Wacana adalah ucapan, percakapan, kata, atau kalimat yang menghubungkan posisi lain dan membentuk satu kesatuan bahasa terlengkap dan terbesar dari kalimat atau klausa dengan kohesi dan koherensi yang tinggi dan berkesinambungan. Untuk menciptakan keutuhan, bagianbagian wacana harus saling berhubungan. Hubungan antarbagian wacana dapat dibedakan menjadi dua jenis, yaitu hubungan benuk yang disebut kohesi dan hubungan makna atau hubungan semantis yang disebut koherensi.ketiga teks wacana yang dibahas di atas dapat digunakan dalam pembelajaran di sekolah. Siswa dapat mengetahui perbedaan kohesi dan koherensi wacana dalam teks cerpen, teks prosedur, dan teks lingkungan. Siswa juga dapat menganalisis ketiga teks tersebut berdasarkan kohesi dan koherensi yang baik dan benar.

\section{B. Saran}

\begin{abstract}
Dalam pembelajaran bahasa Indonesia seorang guru, siswa dan pembaca dapat menjadikan teks cerpen, teks prosedur, teks lingkungan, sebagai perbandingan dalam pembelajaran teks yang lainnya sebagai pembelajaran di sekolah khususnya pada mata pelajaran bahasa Indonesia tentunya. Dalam pembelajaran teks tersebut maka siswa mampu mengidentifikasi struktrur, tata bahasa dan ciri-ciri teks hubungan kohesi dan koherensi yang dipelajari dan kemungkinannya dimanfaatkan dalam pemelajaran di rumah maupun di sekolah.
\end{abstract}




\section{KEPUSTAKAAN}

Amin, Adi Yudi, dkk. 2019. Aktif dan Kreatif Berbahasa Indonesia Untuk Kelas X SMA/MA Jakarta Pusat Perbukuan Departemen Pendidikan Nasional.

https://issuu.com/gunyaya/docs/kelas10_aktif-dan-kreatif-berbahasa-indonesia_adi-/90.

Alamendah. 2014. "Kerusakan Hidup". http://wacanalingkungan.blogspot.com/2015/08/kerusakan-lingkungan-hidup.html?m=1.

Agustina, E, S. 2017. "Pembelajaran Bahasa Indonesia Berbasis Teks: Representasi Kurikulum 2013”. Aksara Jurnal Bahasa dan Sastra. Volume 18. Nomor 1. Halaman 84-99. Diunduh 1 Juni 2020.

Arviyana, M. Ramadhan, S. Tressyalina. 2017. "Pengaruh Model Discovery Learning Berbantuan Media Audiovisual terhadap Keterampilan Menulis Teks Proseedur Siswa Kelas VII SMP Negeri 12 Padang”. Jurnal Pendidikan Bahasa dan Sastra Indonesia. Volume 6. Nomor 2. Halaman 183-191. Diunduh 29 Mei 2020.

Baryadi, P. 2002. Dasar-dasar Analisis Wacana dalam Ilmu Bahasa. Jogjakarta: Pustaka Gondho Suli.

Brilio. 2019. " Cara membuat nasi goreng yang enak" https://brilicious.brilio.net/masak.../20resep-nasi-goreng-sederhana-paling- enak-spesial-dan-praktis-1909309.html

Guci, I. Ramadhan, S. Nursaid. . 2016. "Korelasi Penguasaan Kosakata Bidang Lingkungan Hidup dengan Menulis Karangan Argumentasi tentang Lingkungan Hidup”. Jurnal Pendidikan Bahasa dan Sastra Indonesia. Volume 5. Nomor 2. Halaman 169-174. Diunduh 29 Mei 2020.

Hafizah, T. Ramadhan, S. Ratna, E. 2018. "Kontribusi Keterampilan Membaca Apresiatif Teks Cerpen terhadap Keterampilan Menulis Teks Cerpen”. Jurnal Pendidikan Bahasa dan Sastra Indonesia. Volume 7. Nomor 3. Halaman 394-402. Diunduh 29 Mei 2020.

Hanafiah, W. 2014. "Analisis Kohesi dan Koherensi pada Wacana Buletin Jumat”. Jurnal Penelitian dan Pengembangan Humaniora Epigram. Volume 11. Nomor 2. Halaman 135-152. Diunduh 29 Mei 2020.

Insani, H, R \& Goziyah. 2018. "Kohesi dan Koherensi dalam Koran Bisnis Indonesia dengan Judul Kememperin Jamin Serap Garam Rakyat”. Jurnal Penelitian Pendidikan Bahasa 
Indonesia, Daerah, dan Asing. Volume 1. Nomor 1. Halaman 138-153. Diunduh 29 Mei 2020.

Isodarus, P, B. 2017. "Pembelajaran Bahasa Indonesia Berbasis Teks". Jurnal Ilmiah Keebudayaan SINTESIS. Volume 11. Nomor 1. Halaman 1-11. Diunduh 1 Juni 2020.

Nurfitriani. Bahry, R. Azwardi. 2018. "Analisis Kohesi dan Koherensi dalam Proposal Mahasiswa PBSI Tanggal 23 Desember 2014”. Jurnal Bahasa dan Sastra. Volume 12. Nomor 1. Halaman 39-49. Diunduh 29 Mei 2020.

Putri, I. Atmazaki. Ramadhan, S. 2013. "Pelaksanaan Lesson Study dalam Pembelajaran Bahasa Indonesia Siswa Kelas VII 5 MTsN Lubuk Buaya Padang”. Jurnal Bahasa, Sastra dan Pembelajaran. Volume 1. Nomor 1. Halaman 108-117. Diunduh 29 Mei 2020.

Ramadhan, S. 2008. "Representasi Kesantunan Tindak Tutur Berbahasa Indonesia dalam Pembelajaran di Kelas (Kajian Etnografi Komunikasi)”. Jurnal Diksi. Volume 15. Nomor 2. Halaman 120-136. Diunduh 30 Mei 2020.

Ramadhan, S. Sukma, E. Indriyani, V. 2019. "Environmental Education and Disaster Mitigation Through Language Learning". Journal IOP Conference Series: Earth and Environmental Science. Halaman 1-9. Diunduh 30 Mei 2020.

Ramadhan, S. Sukma, E. Indriyani, V. 2019. "Education and Digital Media Literacy: The Use of Digital Media by Teachers in Middle Schools”. Journal ICLLE. Diunduh 19 Mei 2020.

Siregar, S. 2019. "Analisis Kohesi dan Koherensi Wacana Bahasa Inggris". Jurnal Dewantara. Volume 7. Halaman 39-55. Diunduh 30 Mei 2020.

Sukma, E. Mahjuddin, R. Amelis, R. 2017. "Literacy Media Devolepment in Improving Reading and Writing Skill of Early Class Students in Elementary School Padang Utara Padang". Jurnal Atlantis Press. Volume 118. Halaman 145-150. Diunduh 30 Mei 2020.

Sukma, E. Mahjuddin, R. Habibi, M. 2018. "Literacy Media Models in Improving Reading Skill of Early Class Students in Elementary School”. Journal of Counseling and Educational Technology. Volume 1. Nomor 2. Halaman 33-40. Diunduh 30 Mei 2020.

Sukma, E. Indrawati, T. Suriani, A. 2019. "Penggunaan Media Literasi Kelas Awal di Sekolah Dasar”. Jurnal Inovasi Pendidikan dan Pembelajaran Sekolah Dasar. Volume 3. Nomor 2. Halaman 103-111. Diunduh 30 Mei 2020. 
Widiatmoko, W. 2015. "Analisis Kohesi dan Koherensi Wacana Berita Rubrik Nasional di Majalah Online Detik”. Jurnal Sastra Indonesia. Volume 4. Nomor 1. Halaman 1-12. Diunduh 30 Mei 2020.

Widyaningrum, H, K. 2017. “Analisis Kohesi dan Koherensi Iklan dalam Surat Kabar Kompas”. Jurnal Bahtera. Volume 4. Nomor 7. Halaman 1-11. Diunduh 30 Mei 2020. 